\title{
Characterization of Opiate-mediated Responses of the Feline Ileum and Ileocecal Sphincter
}

\author{
ann Ouyang, Carole J. Clain, William J. Snape, Jr., and Sidney Cohen, \\ Gastrointestinal Section, Department of Medicine, Hospital of the University \\ of Pennsylvania, Philadelphia, Pennsylvania 19104
}

A B S TRACT Although opioid peptides have been demonstrated immunohistochemically in the feline intestine, the action of these peptides is unknown. The aims of this study were: $(a)$ to determine the distal ileal and ileocecal sphincter (ICS) responses to morphine sulfate (MS), methionine enkephalin (ME) and leucine enkephalin (LE); (b) to determine the mechanism by which exogenous opiates mediate these responses; $(c)$ to determine the type of receptor involved in mediating these responses and $(d)$ to ascertain whether endogenous opiate-mediated responses may be vagally induced. The ICS responded to all three opiate agonists with tonic and phasic contractions, the latter being associated with increased spike activity. The $\mathrm{ED}_{\max }$ for ICS pressure response was $1 \mu \mathrm{g} / \mathrm{kg}$ for $\mathrm{ME}, 5 \mu \mathrm{g} / \mathrm{kg}$ for $\mathrm{LE}$, and $150 \mu \mathrm{g} / \mathrm{kg}$ for MS. The distal ileum responded with increased spike activity and phasic contractions. The $\mathrm{ED}_{\max }$ for the ileal motility index response was $1.0 \times 10^{-1} \mu \mathrm{g} / \mathrm{kg}$ for $\mathrm{ME}, 1 \mu \mathrm{g} / \mathrm{kg}$ for LE, and $150 \mu \mathrm{g} / \mathrm{kg}$ for MS. Thus, both sites demonstrated similar dose-response relationships, both responding to at least 100 times lower doses of enkephalins than MS. The ICS contraction preceded ileal contractions. The ileal and ICS response was not antagonized by atropine, hexamethonium, phentolamine, propranolol, cinanserin, or tetrodotoxin. $\mathrm{Nal}$ oxone, $600 \mu \mathrm{g} / \mathrm{kg}$, antagonized the response to the enkephalins while $10 \mu \mathrm{g} / \mathrm{kg}$ antagonized the response to MS. Higher doses of the specific-receptor agonist SKF 10047 and $\kappa$-receptor agonist ketocyclazocine were required before a contractile response was elicited. Electrical stimulation of the cervical vagus induced ICS contraction and a fall in blood pressure. The ICS contractile response but not the blood pressure

Dr. Ouyang is a Measey Foundation Fellow, Department of Medicine, University of Pennsylvania. Address reprint requests to Dr. Ouyang.

Received for publication 9 March 1981 and in revised form 26 October 1981. response was inhibited by naloxone $1 \mathrm{mg} / \mathrm{kg}$. These data indicate: $(a)$ tonic and phasic ICS contraction followed by ileal contraction may be mediated through $\delta$-type opiate receptors located in the muscle membrane and $(b)$ opiate-mediated ICS contraction may be induced during vagal stimulation.

\section{INTRODUCTION}

Opiates were first used by man in the empiric treatment of diarrhea. Studies on the effect of opiates on gastrointestinal motility have been largely performed using morphine sulfate(MS). ${ }^{1}$ Morphine has been demonstrated to prevent castor oil-induced diarrhea and to delay intestinal transit in rats $(1,2)$. The effect can be seen after either peripheral or central administration, the central effect being mediated in the rat via the vagus nerve $(1,3)$. The peripheral opiate action in the canine ileum appears to be mediated via the release of 5-hydroxytryptamine $(5 \mathrm{HT})(4,5)$. The result of delayed intestinal transit with increased contractile activity suggests that the contractions cause functional obstruction to the flow of intestinal contents.

The discovery of opiate receptors in the brain, in 1973 , has led to the identification of endogenous opioid peptides, the endorphins (6-8). The two opioid pentapeptides, methionine enkephalin (ME) and leucine enkephalin (LE), originally isolated from the pituitary, have now been demonstrated immunohistochemically in the brain, the peripheral autonomic nervous system, and the myenteric plexus of the gastrointestinal tract (9-14). In the cat, enkephalinergic nerve fibers have been demonstrated in the pylorus and a vagally induced atropine-resistant pyloric contraction appears to involve opiate receptors (15).

\footnotetext{
${ }^{1}$ Abbreviations used in this paper: $\mathrm{ED}_{50}$, dose giving $50 \%$ of maximal response; 5HT, 5-hydroxytryptamine; ICS, ileocecal sphincter; LE, leucine enkephalin; ME, methionine enkephalin; MS, morphine sulfate.
} 
We have demonstrated that contraction at the ileocecal sphincter (ICS) of the cat can occur via spikedependent and spike-independent mechanisms in a model that involves the simultaneous recording of myoelectrical activity and intraluminal pressures (16).

The aims of this study were: $(a)$ to examine the effect of MS, ME, and LE on the myoelectrical and mechanical activity of the distal ileum and ICS; $(b)$ to elucidate the mechanism and site of this action; $(c)$ to determine the possible endogenous role of such a mechanism in altering ileal and ileocecal function.

\section{METHODS}

Studies were performed in a total of 80 adult domestic cats weighing between 1.8 and $4.0 \mathrm{~kg}$. The animals were fasted for $24 \mathrm{~h}$ before the study. The animals were sedated using ketamine hydrochloride (Ketalar, Parke-Davis, Morris Plains, N. J.), $10 \mathrm{mg} / \mathrm{kg}$ i.m. After sedation, the animal was strapped to an animal board, and the right femoral vein was exposed and cannulated using a 21-G venocatheter under local anesthesia ( $1 \%$ xylocaine). Anesthesia was achieved and maintained by intravenous infusion of chloralose urethan $(5 \mathrm{~g} /$ $100 \mathrm{ml}$ chloralose in polyethylene glycol (PEG 200), $8 \mathrm{~g} / 100$ $\mathrm{mg}$ urethan) at a dose of $1 \mathrm{ml} / \mathrm{kg}$. A tracheostomy was performed to allow assisted ventilation, using a small animal respirator (Harvard Apparatus Co., Inc., Mass.) if respirations became shallow. A heparinized cannula (21-G venocatheter) was inserted into the right femoral artery and connected to an external transducer (Statham P231A, Statham Instruments, Inc., Oxnard, Calif.) for constant blood pressure monitoring. Patency of the intravenous cannula was maintained by slow infusions of $0.9 \%$ saline $\left(15 \mathrm{~cm}^{3} \mathrm{~h}^{-1}\right)$. The arterial cannula patency was maintained by intermittent flushing with saline (2-ml bolus) when the arterial tracing showed evidence of failure to record accurately. The body temperature was maintained at $37^{\circ} \mathrm{C}$ by means of a heat lamp and was monitored rectally and intraabdominally. The intraabdominal contents were exposed through a midline incision. The distal ileum, ICS, and colon were identified visually and the colon emptied of feces through a distal incision, at the level of the pelvic muscle floor.

Intraluminal pressures were measured using a triple-lumen manometry tube with three side orifices (1.2 mm Diam) spaced $2 \mathrm{~cm}$ apart over the distal segment of the unit. Each lumen was connected to external transducers (Statham P231A) with a linear calibration of 0-250 $\mathrm{mm} \mathrm{Hg}$. Each catheter was continuously infused with distilled water, warmed to $37^{\circ} \mathrm{C}$, using a Harvard infusion pump (Harvard Apparatus Co., Inc., Natick, Mass.) at a rate of $0.764 \mathrm{ml} /$ $\mathrm{min}$. This rate of infusion gave a $>250-\mathrm{mm} \mathrm{Hg} / \mathrm{s}$ rise in pressure upon occlusion of the recording orifices.

The manometry tube was inserted via the distal colonic incision and introduced through the ICS into the distal ileum. All orifices were placed in the distal ileum and the manometry apparatus was then withdrawn towards the colon to determine the length and amplitude of the ICS high pressure zone. This corresponded to the anatomical ICS, which can be palpated at the time of the study as a thickening in the muscle. At the end of the study, if the bowel is opened, the ICS can be seen as a thickening of the circular muscle in the same area as determined by palpation and by manometric pressure recording. The manometry tube was positioned with its middle orifice in the ICS at the site of the high pressure. Small tapes were present on either side of the middle orifice on the manometry tube and could be palpated. The manometry apparatus was fastened in position by the placement of 4-0 silk sutures through the bowel and these tapes. Two 2-mm-Diam polyvinyl tubes with side orifices were placed through a $4 \times 4-\mathrm{mm}$ incision at least $20 \mathrm{~cm}$ proximal to the ICS and via the distal colonic incision previously described. These catheters prevented distension of the ileum and colon from catheter perfusate, allowing drainage of effluent by gravity.

Myoelectrical activity was recorded using five bipolar, silver-silver chloride electrodes sutured to the serosa at $2-\mathrm{cm}$ intervals. The distance between the electrode poles was 3 $\mathrm{mm}$. Three electrodes were sutured to the ileum, starting $6.0 \mathrm{~cm}$ proximal to the ICS. One electrode was sutured at the ICS, identified as described earlier, and the fifth electrode was sutured $2 \mathrm{~cm}$ distal to the ICS on the proximal colon. The electrodes were oriented with the poles in the direction of the longitudinal muscle. Each electrode was connected via a junction box to a rectilinear recorder (Beckman RM Dynograph, Beckman Instruments, Inc., Fullerton, Calif.) through AC couplers (9853A). Studies were performed with a time constant of $1.0 \mathrm{~s}$ and a low filter frequency of $0.16 \mathrm{~Hz}$ and a high frequency filter of $100 \mathrm{~Hz}$. A ground electrode was placed in the subcutaneous tissue of a hind limb.

Respirations were recorded by a belt pneumograph placed around the chest and attached to a pressure transducer (Statham $\mathrm{P} 32$, venous). The myoelectrical activity, intraluminal pressures, arterial blood pressure, and respirations were recorded simultaneously on a multichannel Beckman rectilinear ink-writing recorder (Beckman Instruments, Inc.).

The segment of bowel containing the distal ileum, ICS and proximal colon was kept moist with normal saline and drying was reduced by covering the exposed bowel with clear polyethylene wrap. A period of at least $\mathbf{l} \mathrm{h}$ was allowed for equilibration after manipulation of the bowel during each study.

The following opiates were studied: MS (Eli Lilly \& Co., Indianapolis, Ind.) $1.0 \times 10^{-2}$ to $3.0 \times 10^{2} \mu \mathrm{g} / \mathrm{kg}, \mathrm{ME}$ (Sigma Chemical Co., St. Louis, Mo.) $1.0 \times 10^{-5}$ to $5 \mu \mathrm{g} / \mathrm{kg}$, and LE (Sigma Chemical Co.) $1.0 \times 10^{-5}$ to $10 \mu \mathrm{g} / \mathrm{kg}$. The specific opiate receptor agonists SKF 10,047 (National Institute on Drug Abuse, Rockville, Md.), and ketocyclazocine (SterlingWinthrop Research Institute, Rensselaer, N. Y.) were used in studies to determine the type of opiate receptor present.

A dose-response curve was established for each opiate agonist. Different agonists were used in different animals with at least five studies used for each agonist dose. The doses were given intravenously in a random order with at least $\mathbf{4 5}$ min between doses to allow a return of the bowel activity to base line. When the maximum effective dose had been established, this dose was used for studying the effect of antagonists.

The mechanism of the ICS response to opiates was investigated using the following antagonists: atropine sulfate (Elkins-Sinn, Inc., Cherry Hill, N. J.) $30 \mu \mathrm{g} / \mathrm{kg}$, a cholinergic muscarinic antagonist (17); hexamethonium bromide (Sigma Chemical Co.) $20 \mathrm{mg} / \mathrm{kg}$, a ganglion blocking drug; phentolamine mesylate (Regitine mesylate Ciba Pharmaceutical Company, Summit, N. J.), $1 \mathrm{mg} / \mathrm{kg}$, an adrenergic antagonist; and propranolol hydrochloride (Inderal, Ayerst Laboratories, New York.) $1 \mathrm{mg} / \mathrm{kg}$, a $\beta$-adrenergic antagonist (18). A dose-response curve was established for $5 \mathrm{HT}$ and the effect of cinanserin hydrochloride (Squibb \& Sons Inc., Princeton, N. J.), $250 \mu \mathrm{g} / \mathrm{kg}$, a dose which blocks the ICS contractile response to $5 \mathrm{HT}$, on the ICS response to opiates was determined. The neurotoxin tetrodotoxin (Calbiochem- 
Behring Corp., American Hoechst Corp., San Diego, Calif.), 1-3 $\mu \mathrm{g} / \mathrm{kg}$, was also used. This dose range proved effective in inhibiting the contractile response of the ICS to direct vagal stimulation and DMPP (1,1-dimethyl-4-phenylpiperazinium iodide), 50-100 $\mu \mathrm{g} / \mathrm{kg}$. Different antagonists were studied on separate days. A control response to the maximal effective dose of opiates was established at least $1 \mathrm{~h}$ before any antagonist was administered. The antagonist under study was then injected intravenously 1-3 min before a repeated injection of opiate. At the end of the study, the opiate was again administered to determine a return of ICS response.

All drugs were diluted to a volume of $1 \mathrm{ml}$ in normal saline, and administerd as an intravenous bolus except for naloxone which, at the dose of $1 \mathrm{mg} / \mathrm{kg}$, was diluted in 5 $\mathrm{ml}$ saline and infused over 2 -min period. The cannula was flushed with $1 \mathrm{ml}$ normal saline following each bolus injection.

The effect of cervical vagal integrity on the ICS response to opiates was investigated by determining the ICS response to opiates before and after bilateral cervical vagal section. An anterior midline incision was made in the neck. The left and right vagal trunks were identified within the carotid sheath behind and in between the internal jugular vein and the common carotid artery. The vagi were then individually isolated and each was sectioned. Nerve identity was confirmed by electrical induction of bradycardia and arterial hypotension during nerve stimulation. The effect of electrical stimulation on the myoelectrical and mechanical activity of the distal ileum, ICS, and proximal colon were studied. The effect of intravenous naloxone on the contractile response of the ICS to vagal stimulation $(5 \mathrm{~ms}, 10 \mathrm{~Hz}, 10 \mathrm{~V}$ ) was determined.

The base-line ileal, ICS, and colonic pressures were measured in millimeters of mercury with the initial ileal pressure used as zero reference. Values were obtained at the midrespiratory cycle. The ICS response to drugs was recorded as the maximal pressure seen within 2 min of the stimulus, again in the midrespiratory cycle. The maximum pressure during each minute for 10 min following a stimulus was also recorded, as was the character of the response.

A contraction was considered phasic if there was a rapid increase in pressure such that it reached a peak and returned to base-line levels within the time interval of one slow wave. A contraction was considered tonic if the pressure remained elevated during consecutive slow waves. Respirations were recorded simultaneously so that base-line variations in ICS pressure due to respiratory movements were not included as phasic contractions.

The myoelectrical activity was analyzed for $5 \mathrm{~min}$ before each stimulus and a least $10 \mathrm{~min}$ after each stimulus. The number of slow waves per minute and the number of slow waves with spike bursts were noted per minute for these time intervals. The time relationship between spike bursts was analyzed to determine if a response was propagated antegrade or retrograde. If, within the minute following the administration of opiates, there was spiking in the most distal ileal lead before the ICS lead the response was labeled an antegrade response. If the response occurred in the ICS lead before the ileal lead it was considered retrograde. The spike activity on the adjacent leads had to be seen within the time interval of one slow wave in order to consider the response as retrograde. The terms were not meant to imply actual propagation of spike activity but the temporal relationship between spike activity in adjacent areas of the bowel. The delays between the time of injection of the opiate and the onset of the contractile response in the ICS and most distal ileal lead were also determined.
The ileal contractile response was recorded as a motility index, as the response was phasic. The motility index was calculated as the mean amplitude of contraction for $2 \mathrm{~min}$ $X$ number of contractions for $2 \mathrm{~min}$.

Statistical analysis was performed using Student's $t$ test to compare the ICS pressure after opiate stimulation to baseline levels, and to the response after administration of each antagonist. The ileal motility index was analyzed similarly. Results are expressed as a mean $\pm \mathrm{SE}$.

\section{RESULTS}

Ileocecal sphincter response to opiate. MS, ME, and LE, when given as an intravenous bolus injection, resulted in contraction of the ICS. The ileocecal response consisted of both tonic and phasic components (Fig. 1). The predominance of the tonic vs. the phasic components varied between animals. A phasic response alone was not seen. The phasic response of increased ICS pressure was associated with spike activity at the ICS electrode. The ICS response was seen following a delay after intravenous injection of $12.7 \pm 1.3$ $\mathrm{s}$ for MS, $12.2 \pm 0.8 \mathrm{~s}$ for ME, and $15.0 \pm 1.5 \mathrm{~s}$ for LE at their maximally effective doses. The duration of the total response, defined as the length of time following the injection of the opiate agonist during which the ICS pressure was greater than base-line pressure, varied depending on the animal under study. In a given animal, the response was shorter at lower doses of agonist than at higher doses but there was considerable overlap. At the lowest dose eliciting an ICS response the duration of contraction was between 1 to $2 \mathrm{~min}$. The duration of the total response to the maximally effective dose of MS was $9.2 \pm 2.2 \mathrm{~min}$, to $\mathrm{LE}$ was $6.3 \pm 2.0 \mathrm{~min}$, and to $\mathrm{ME}$ was $3.76 \pm 0.5 \mathrm{~min}$. Thus, the response to all opiates was short-lived, the 45 -min rest period between each agonist dose being adequate to allow return to base line. No tachyphylaxis was seen when the same opiate dose was repeated after this time interval.

When a tonic contraction only was seen at the ICS, no accompanying spike activity was seen at the ICS electrode. After MS $17.25 \%(10 / 58)$ of ICS responses were purely tonic; $37.3 \%(26 / 70)$ and $41.2 \%(14 / 34)$ were tonic after $\mathrm{ME}$ and $\mathrm{LE}$, respectively. When a response consisted of both phasic and tonic responses simultaneously, the spike activity was seen to correlate with the phasic contractions. The phasic response was of shorter duration than the tonic response, the latter persisting in the absence of spike activity. Thus, both spike-dependent and spike-independent contractions of the ICS were seen in response to opiate agonists. The spike-independent contraction was the more persistent response.

A dose-response relationship was seen for each of the opiate agonists (Figs. 2 and 3 ). The maximum ICS pressure change was the same for each agonist. 


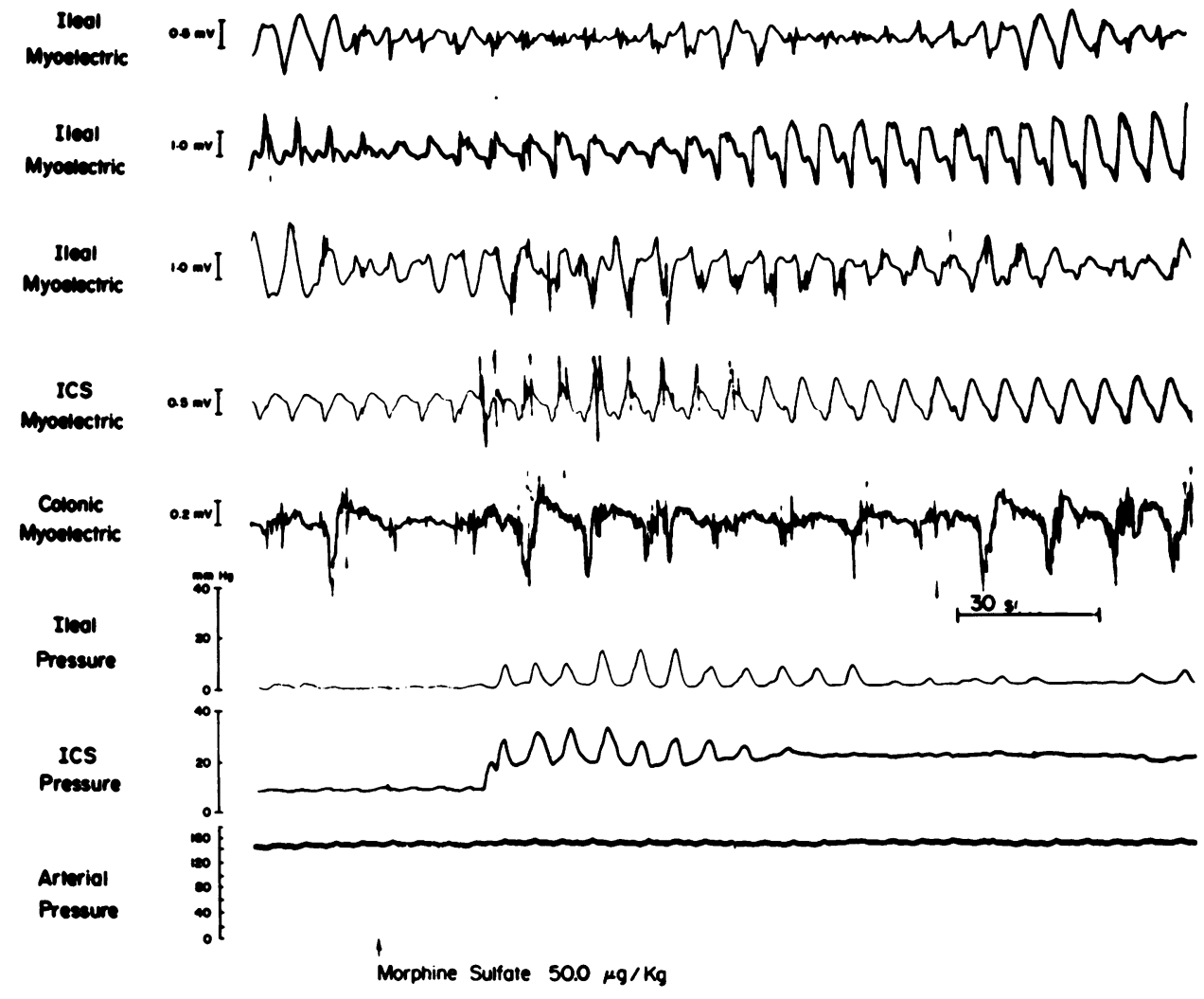

FIGURE 1 Recording of the myoelectrical activity of the distal ileum, ICS and colon, and intraluminal pressures in the distal ileum and ICS after $50 \mu \mathrm{g} / \mathrm{kg}$ MS ( $\uparrow$. The ICS pressure showed both a tonic and phasic increase.

(27.2 $\pm 3.5 \mathrm{~mm} \mathrm{Hg}$ for $\mathrm{MS}, 28.0 \pm 3.1 \mathrm{~mm} \mathrm{Hg}$ for $\mathrm{ME}$, and $28.1 \pm 6.8 \mathrm{~mm} \mathrm{Hg}$ for $\mathrm{LE}$ ). The $\mathrm{ED}_{50}$ (dose giving $50 \%$ of maximal response) was $10 \mu \mathrm{g} / \mathrm{kg}$ for MS, 1.0 $\times 10^{-2} \mu \mathrm{g} / \mathrm{kg}$ for ME, and $1.0 \times 10^{-3} \mu \mathrm{g} / \mathrm{kg}$ for $\mathrm{LE}$. Maximal responses were seen at $150 \mu \mathrm{g} / \mathrm{kg}$ MS, $1 \mu \mathrm{g} /$

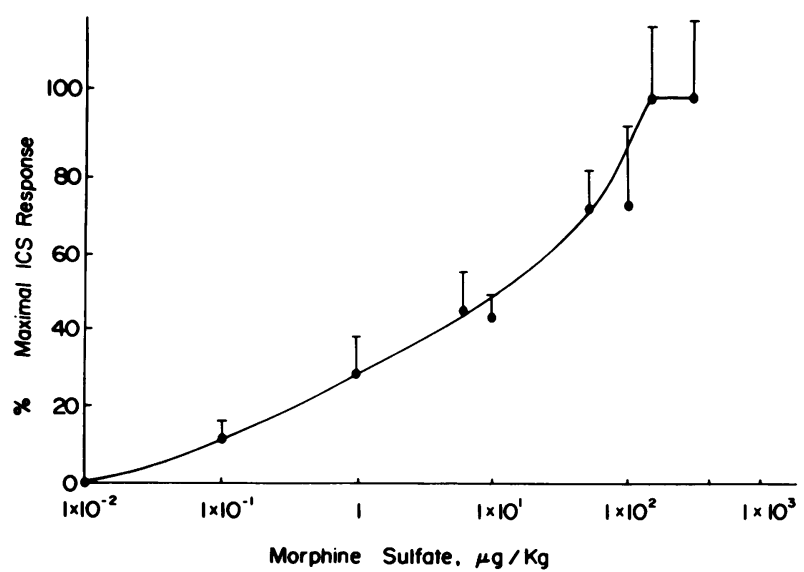

FIGURE 2 Change in ICS pressure after increasing doses of MS. Changes in pressure were significant $(P<0.05)$ at doses $>3 \mu \mathrm{g} / \mathrm{kg}$ MS. $\mathrm{kg} \mathrm{ME}$, and $5 \mu \mathrm{g} / \mathrm{kg} \mathrm{LE}$. Thus the ICS was at least 100 times more sensitive to the enkephalins than to MS.

Ileal response to opiates. A phasic contractile re-

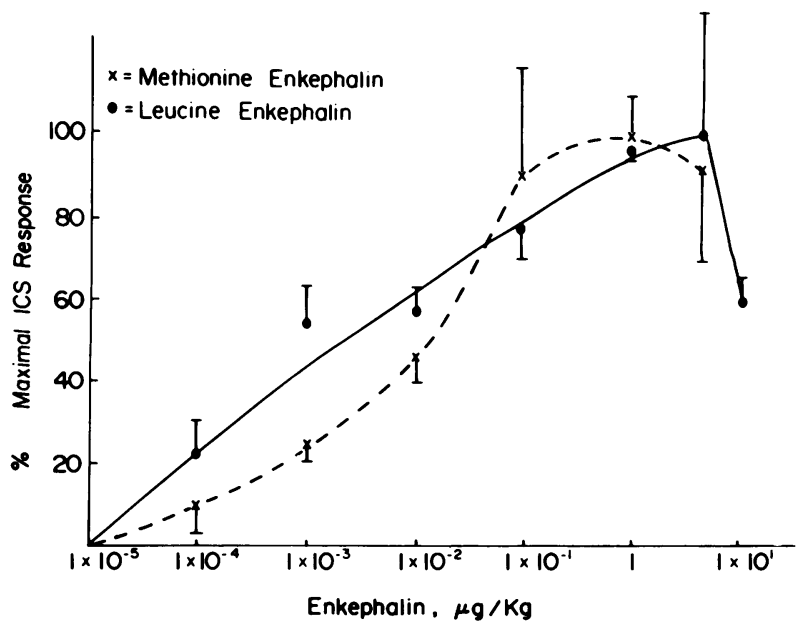

Figure 3 Change in ICS pressure after increasing doses of $\mathrm{ME}$ and LE. Significant increases in pressure $(P<0.05)$ were noted at doses $>1.0 \times 10^{-3} \mu \mathrm{g} / \mathrm{kg} \mathrm{ME}$ and $>5.0 \times 10^{-3} \mu \mathrm{g} /$ $\mathrm{kg} \mathrm{LE}$. 
sponse of the distal ileum was seen after intravenous injection of MS, ME, and LE. The motility index was calculated over a 2-min interval before and after the injection of an opiate. As with the ICS, there was an ileal dose-response relationship to opiate agonists (Fig. 4). The maximum absolute change in motility index above baseline was $107.9 \pm 17.13$ for ME, $102 \pm 39.0$ for MS, and 72.5 \pm 17.82 for LE. These are not different statistically. A maximum ileal response was seen after $150 \mu \mathrm{g} / \mathrm{kg} \mathrm{MS}, 1 \mu \mathrm{g} / \mathrm{kg} \mathrm{LE}$, and $1 \times 10^{-1} \mu \mathrm{g} / \mathrm{kg} \mathrm{ME}$. The $\mathrm{ED}_{50}$ for the ileal response was $25 \mu \mathrm{g} / \mathrm{kg} \mathrm{MS}, 1.5$ $\times 10^{-2} \mu \mathrm{g} / \mathrm{kg} \mathrm{LE}$, and $8.0 \times 10^{-3} \mu \mathrm{g} / \mathrm{kg} \mathrm{ME}$. The distal ileum, like the ICS, was $\sim 10^{2}$ to $10^{3}$ times more sensitive to the enkephalins than to MS.

Relationship between ICS and ileal response. The onset of spike activity and pressure changes in the ICS after the injection of maximal doses of $\mathrm{ME}$ were seen significantly earlier than the ileal spike activity and pressure changes. Ileal spike delay was $13.4 \pm 1.0 \mathrm{~s}$, ICS spike delay being $12.2 \pm 0.8 \mathrm{~s}(P<0.05, n=18)$; ileal pressure response delay was $17.6 \pm 1.4 \mathrm{~s}$, ICS pressure delay being $13.8 \pm 1.1 \mathrm{~s}(P<0.005, n=18)$. The delay to colonic spike activity $(21.5 \pm 1.9 \mathrm{~s})$ was significantly greater than that to ileal activity $(P<0.005)$. The spiking in the ileal leads was either simultaneous in all three ileal leads recorded or was seen later in progressively more proximal ileal leads suggesting retrograde propagation. Section of the bowel proximal to the ICS did not abolish the ileal, ICS, or colonic response to opiates. Thus each segment of the bowel investigated responds to exogenous opiates and is not dependent on the activation of an adjacent section of the bowel with myogenic propagation. The meaning of the time relationship between the ICS and ileal re-

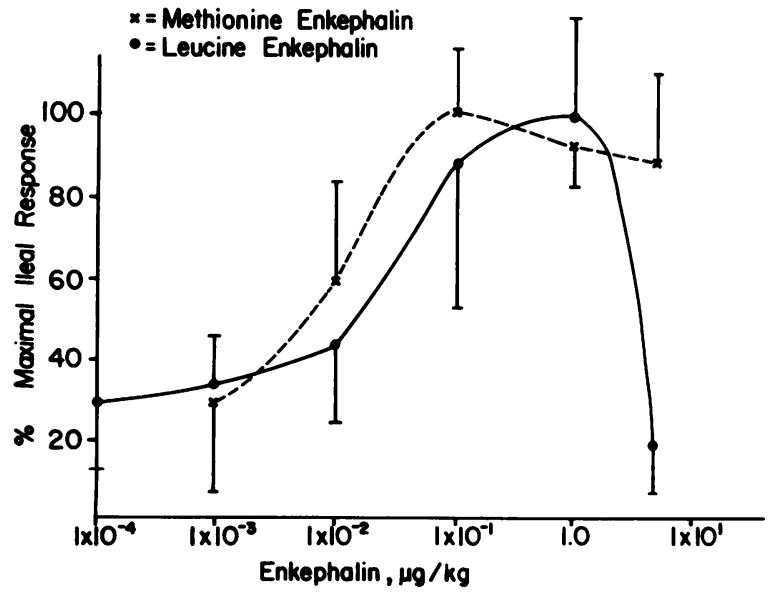

Figure 4 Change in motility index of the distal ileum after increasing doses of $\mathrm{ME}$ and $\mathrm{LE}$. Changes in motility index were significant $(P<0.05)$ at doses $>1.0 \times 10^{-3} \mu \mathrm{g} / \mathrm{kg} \mathrm{ME}$ and between $1.0 \times 10^{-2}$ and $1 \mu \mathrm{g} / \mathrm{kg} \mathrm{LE}$.

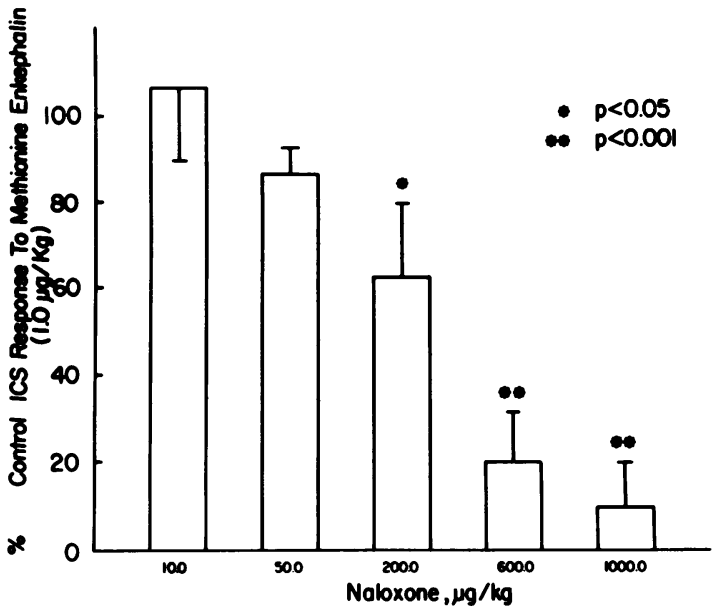

Figure 5 Effect of different doses of naloxone on the ICS pressure response to the maximally effective dose of $\mathrm{ME}$. $1,000 \mu \mathrm{g} / \mathrm{kg}$ naloxone completely inhibited the ICS response to $\mathrm{ME}$.

sponses is not clear. Differences in blood flow rates to different parts of the bowel may explain the apparent retrograde propulsion in response to exogenous opiates.

Effect of antagonists on the ICS opiate response. Naloxone at a dose of $10 \mu \mathrm{g} / \mathrm{kg}$ antagonized the effect of the maximal dose of MS at the ICS by $92.9 \pm 4.0 \%$ $(P<0.01)$. The effect of different doses of naloxone on the ICS response to ME $1 \mu \mathrm{g} / \mathrm{kg}$ is shown in Fig. 5. $1,000 \mu \mathrm{g} / \mathrm{kg}$ naloxone abolished the ICS response to maximal doses of ME $1 \mu \mathrm{g} / \mathrm{kg}$ with the ICS contraction being reduced to $11 \pm 10.5 \%$ of control $(P$ $<0.001, n=6)$. Naloxone did not alter the ICS or ileal response to submaximal $(30 \mu \mathrm{g} / \mathrm{kg})$ or maximal doses of bethanechol $(50 \mu \mathrm{g} / \mathrm{kg})$. The ICS response to phenylephrine $(100 \mu \mathrm{g} / \mathrm{kg})$ was also not affected by naloxone $1,000 \mu \mathrm{g} / \mathrm{kg}$.

The effect of atropine, hexamethonium, phentolamine, propranolol, cinanserin, and tetrodotoxin on the ICS response to ME was next studied. The doses chosen were those shown to antagonize the effect of their respective maximal agonist doses $(17,18)$. Each response was compared with a control response in the same animal with a control agonist injection given at least $30 \mathrm{~min}$ before the antagonist effect was investigated and at least $1.5 \mathrm{~h}$ after the antagonist was given. ME $1 \mu \mathrm{g} / \mathrm{kg}$ caused ICS contraction that was $88.0 \pm 11.73 \%$ of control following atropine $30 \mu \mathrm{g} / \mathrm{kg}$ $(P>0.05, n=11), 111.6 \pm 9.9 \%$ of control following phentolamine $1 \mathrm{mg} / \mathrm{kg}(P>0.05, n=6), 82.3 \pm 13.3 \%$ of control following propranolol, $1 \mathrm{mg} / \mathrm{kg}(P>0.05$, $n=6$ ), and $118.2 \pm 24.1 \%$ of control following hexamethonium, $20 \mathrm{mg} / \mathrm{kg},(P>0.05, n=5)$.

5HT caused a variable response at the ICS when given alone at intravenous doses of $10-40 \mu \mathrm{g} / \mathrm{kg}$. In 
$22.7 \%$ of animals, a dose of $40 \mu \mathrm{g} / \mathrm{kg} 5 \mathrm{HT}$ resulted in an initial relaxation of the ICS before the contractile response. The contractile portion of the ICS response to 5HT appears dose dependent with a response of $12.8 \pm 5.08 \mathrm{~mm} \mathrm{Hg}$ to $10 \mu \mathrm{g} / \mathrm{kg} 5 \mathrm{HT}$, of $14.7 \pm 2.8 \mathrm{~mm}$ $\mathrm{Hg}$ to $20 \mu \mathrm{g} / \mathrm{kg} 5 \mathrm{HT}$, and $13.75 \pm 1.2 \mathrm{~mm} \mathrm{Hg}$ to 40 $\mu \mathrm{g} / \mathrm{kg} 5 \mathrm{HT}$.

Methysergide in doses of up to $800 \mu \mathrm{g} / \mathrm{kg}$ did not antagonize the ICS contractile response to 5HT. Cinanserin hydrochloride, another 5HT antagonist, inhibited the ICS contractile response to $5 \mathrm{HT}$ when given at a dose of $250 \mu \mathrm{g} / \mathrm{kg}$ to $20 \pm 22.3 \%$ of control ( $P$ $<0.005)$. In $50 \%$ of the time $(n=6)$ the response to 5HT was converted to a purely relaxation response. Cinanserin at this dose $(250 \mu \mathrm{g} / \mathrm{kg})$ did not inhibit the ICS response to ME $(P>0.10)$, nor to MS $(P>0.10)$. The ICS response to ME in the presence of cinanserin was $112.3 \pm 26.5 \%$ of control response.

Tetrodotoxin was infused intravenously at doses between 2-3 $\mu \mathrm{g} / \mathrm{kg}$ until spontaneous respirations stopped or the ICS contractile response to vagal stimulation was abolished. Tetrodotoxin at these doses antagonized vagally induced or 1,1-dimethyl-4-phenylpiperazinium iodide $(50-100 \mu \mathrm{g} / \mathrm{kg})$-stimulated ICS contraction. Contraction of the ICS induced by adjacent ileal field stimulation $(10 \mathrm{~V})$ was also abolished. The injection of tetrodotoxin was accompanied by arterial hypotension with a fall of arterial pressure by $71.1 \pm 6.62$ $\mathrm{mm} \mathrm{Hg}$ in $100 \%$ of animals. In $37.5 \%(6 / 16)$ animals, no ICS contractile response was seen. In the remaining 10 animals, phasic and tonic contractions of the ICS with a maximum change in ICS pressure of $15.2 \pm 4.13$ $\mathrm{mm} \mathrm{Hg}$ was seen. The ICS contraction lasted from 2 to $>20 \mathrm{~min}$. Phasic contractions of the ileum were seen in the same animals. Both ileal and ICS contractions persisted about the same length of time. Higher doses of tetrodotoxin were lethal to the animals.

When the ileal and ICS contractions had returned to base line, ME $(1 \mu \mathrm{g} / \mathrm{kg})$ was again given. The ICS response to $\mathrm{ME}$ after tetrodotoxin was $92.3 \pm 7.6 \%$ of the control response $(P>0.05)$, suggesting a response mediated by smooth muscle membrane receptors. The ICS contractile response to $1 \times 10^{-2} \mu \mathrm{g} / \mathrm{kg} \mathrm{ME} \mathrm{(ap-}$ proximate $\mathrm{ED}_{50}$ for $\mathrm{ME}$ ) was also unaltered by tetrodotoxin.

Effect of antagonists on the ileal opiate response. $200 \mu \mathrm{g} / \mathrm{kg}$ naloxone antagonized the ileal motility index response to $\mathrm{ME}, 1 \mu \mathrm{g} / \mathrm{kg}$, to $50.4 \pm 15.6 \%$ of control response while naloxone $1,000 \mu \mathrm{g} / \mathrm{kg}$ completely antagonized the ileal response to $\mathrm{ME}$.

After atropine $(30 \mu \mathrm{g} / \mathrm{kg})$, the ileal response to $\mathrm{ME}$ $(1 \mu \mathrm{g} / \mathrm{kg})$ was $84.4 \pm 9.8 \%$ of control $(P>0.05)$, after cinanserin, $(250 \mu \mathrm{g} / \mathrm{kg})$ the response to $\mathrm{ME}$ was $137.5 \pm 45.3 \%$ of control $(P>0.05)$, and after tetrodotoxin the ileal response to $\mathrm{ME}$ was $140.1 \pm 37.5 \%$ of control $(P>0.05)$. Thus, the ileal response to Met-enkephalin was antagonized by high doses of naloxone but not by atropine, cinanserin, or tetrodotoxin.

Characterization of opiate receptors. The relative potency of enkephalins compared with morphine, and the resistance of the enkephalin response to naloxone suggest that the responses are mediated by $\delta$-receptors. The receptors in this area were characterized further by determining the dose-response to the fairly specific opiate receptor agonists SKF 10047 (specific for $\sigma$-receptors, $293.84 \mathrm{~mol} \mathrm{wt}$ ) and ketocyclazocine (specific for $k$-receptors, $285.4 \mathrm{~mol} \mathrm{wt}$ ). The doses on a molar basis were about threefold greater than the enkephalins. No ICS response was seen to ketocyclazocine before a dose of $1 \mathrm{mg} / \mathrm{kg}$ was given. The $E D_{\max }$ for the ileal motility response after ketocyclazocine was 50 $\mu \mathrm{g} / \mathrm{kg}$ and after SKF 10047 was $50 \mu \mathrm{g} / \mathrm{kg}$. The $\mathrm{ED}_{50}$ for the ileal response with ketocyclazocine was 5.0 $\times 10^{-1} \mu \mathrm{g} / \mathrm{kg}$ and for SKF 10047 was $1 \mu \mathrm{g} / \mathrm{kg}$ compared with $8.0 \pm 10^{-3} \mu \mathrm{g} / \mathrm{kg}$ for ME. Thus the predominant opiate receptor at the distal ileum and ICS appears to be of the $\delta$-type because of the relative insensitivity to these other agonists.

Effect of vagal section or vagal stimulation. Bilateral cervical vagotomy did not alter the maximal response of the ICS to opiates. In those cats undergoing vagotomy, the ICS response to $1 \mu \mathrm{g} / \mathrm{kg}$ ME before vagotomy was $24.5 \pm 2.8 \mathrm{~mm} \mathrm{Hg}$ and after vagotomy the response was $23.6 \pm 3.8 \mathrm{~mm} \mathrm{Hg}(P>0.05)$. Vagal stimulation resulted in a tonic and phasic ICS contraction as is shown in Fig. 6. The ICS pressure response but not the arterial pressure response to peripheral cervical vagal stimulation $(5 \mathrm{~ms}, 10 \mathrm{~Hz}, 10$ V) was inhibited by high doses of naloxone (Fig. 7). This observation suggests that ICS contraction to vagal stimulation may in part be mediated via opiate receptors.

\section{DISCUSSION}

Immunohistochemical studies have demonstrated the presence of enkephalinergic fibers and cell bodies in the myenteric plexus of the feline intestine with an increased density at the sphincters $(14,15)$. The physiological effect of opiates on the motility of the ICS has not been described. The present studies demonstrate a dose-related and highly sensitive response of both the distal ileum and the ICS to MS and the enkephalins. Because of their rapid metabolism, it has been suggested that the enkephalins cannot elicit a peripheral response if given intravenously, (19-21). The dose-response curves of the ileum and ICS demonstrate a response to enkephalins at $>100$ times lower doses than morphine (molecular weights being similar). These areas are probably even more sensitive to 
MYEEALCTRIC

ILEAL

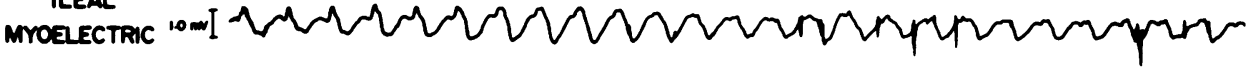

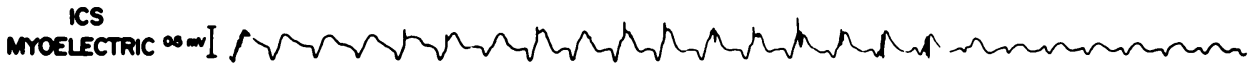

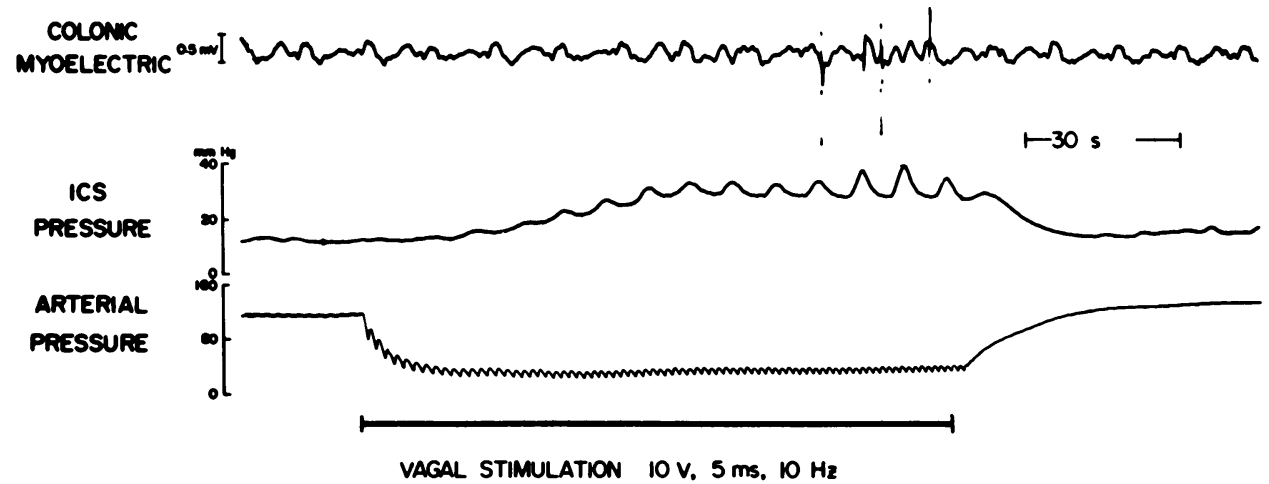

FIgURE 6 Recording of myoelectrical activity at the distal ileum and ICS and colon, intraluminal pressures at the ICS and arterial blood pressure during electrical stimulation $(5 \mathrm{~ms}$, $10 \mathrm{~Hz}, 10 \mathrm{~V}$ ) of the cervical vagus nerve. The ICS pressure showed both tonic and phasic increases during vagal stimulation.

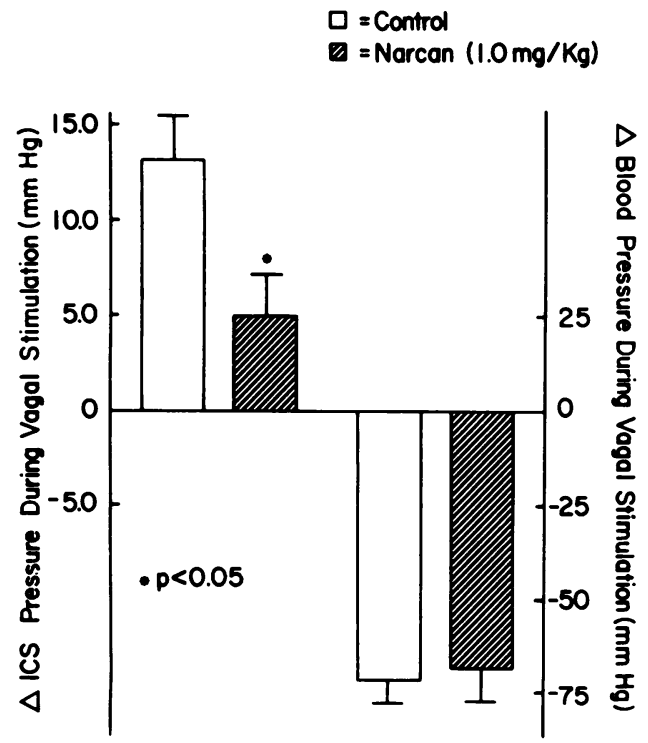

Figure 7 Effect of infusion of $1 \mathrm{mg} / \mathrm{kg}$ naloxone on the ICS pressure response and the arterial blood pressure response during vagal stimulation. Naloxone inhibited the ICS pressure response but not the blood pressure to vagal stimulation. enkephalins than to morphine since the enkephalins are rapidly metabolized. The effect of enkephalins on feline intestinal motility has not been previously described. The effect of morphine has been investigated in the duodenum and ileum $(22,23)$. In the absence of vomiting, no intestinal electrical activity response was described in a chronic cat preparation. In these studies, electrodes were spaced widely apart and effects over short distances of bowel would not be recognized. Also, the distal ileum and ICS were not investigated. The ICS response we have described was both a tonic and phasic contraction. We have previously demonstrated that the ICS responds to stimuli by both spike-dependent phasic contractions and spike-independent tonic contractions (16). The type of receptors present on the two areas appears identical in view of the relative sensitivity of the distal ileum and ICS to the opiate agonists. The responses of the two areas are coordinated such that ICS contraction precedes contraction of the distal ileum. Such organization of contraction might be expected to impede aborad flow of intestinal contents. Our model, however, cannot separate the effects of differential blood flow to different areas. The evidence of similar sen- 
sitivity of these areas to the agonists could be explained either by the presence of receptors only on the ileum with propagation of activity to the ICS, the presence of receptors only at the ICS with retrograde propagation to the distal ileum, or the presence of similar receptors at both the distal ileum and ICS. The first alternative is unlikely because the response is seen first at the ICS. Section of the bowel proximal to the ICS did not abolish either the distal ileal response or the ICS response. Thus, receptors appear to be present both in the distal ileum and the ICS.

The opiate receptors appear to be present on the smooth muscle membrane. The response to enkephalins was not antagonized by the neural antagonist tetrodotoxin, or by the other selective antagonists.

The responses of the ICS and ileum to the selective opiate receptor agonists suggest a predominantly $\delta$-receptor. There was marked sensitivity of both sites to the enkephalins and relative insensitivity to the $\mu$-receptor agonist MS, the $\sigma$-receptor agonist SKF 10047, and the $k$-receptor agonist ketocyclazocine. The response seen to higher doses of these other agonists may still reflect their interaction with $\delta$-receptors. The orders of relative potency of the different agonists at the ileum and the ICS are the same. The relative potency of $\mathrm{ME}$ at the ICS compared with the other agonists seems greater than its relative potency at the ileum, suggesting that the population of receptors may not be identical at the two sites. Several opiate receptors have been demonstrated in the central nervous system but have not been well characterized in the intestine (24-27). The guinea pig ileum has been used in the bioassay of morphine but is different in response to opiates than most mammalian intestinal smooth muscle. Opiates depress electrically induced smooth muscle contraction in the guinea pig (28-31).

The action of morphine on the isolated dog ileum and on the rat intestinal transit may be mediated via the release of $5 \mathrm{HT}(2,4,5)$. We have found, like Burks (4), that the type of 5HT antagonist used is important as methysergide did not inhibit the contractile effect of 5HT on the cat intestine. Doses of cinanserin that inhibited the maximal effect of 5HT did not antagonize the effect of enkephalins. This apparent discrepancy in findings may be due to a species difference in opiate receptors. A difference in the effects of $\mathrm{ME}$ and morphine on canine ileal myoelectrical activity would also suggest a species difference (32).

Enkephalinergic fibers have been demonstrated in the mammalian vagus nerve and the sympathetic ganglia $(14,15)$. Naloxone antagonized an atropine- and guanethidine-resistant pyloric sphincter contraction induced by efferent stimulation of the cervical vagi in the cat (15). We have demonstrated that electrically stimulated vagal-induced contraction of the ICS can also be blocked by doses of naloxone, $1 \mathrm{mg} / \mathrm{kg}$ or higher. Vagally induced ICS contraction is also blocked by adequate doses of hexamethonium or atropine (17), suggesting the presence of nicotinic and muscarinic receptors in the neural pathway. The antagonism of vagal stimulation by these agents suggests that acetylcholine may release an enkephalin at the smooth muscle membrane of the intestine or the myenteric plexus. The failure of tetrodotoxin or atropine to antagonize the effect of the enkephalins strongly favors that the receptor is on the smooth muscle membrane. A nonspecific antagonist effect of naloxone is also possible but naloxone did not reduce the ICS response to maximal or submaximal doses of other agonists.

In summary, we have characterized the ICS and distal ileal response to opiates in the cat and demonstrated that the response to exogenous opiates may be mediated via $\delta$-receptors on the distal ileal and ICS smooth muscle. The organization of this response with ICS contractions preceding distal ileal contraction might be consistent with increasing impedence to the flow of intestinal contents. An endogenous role of opiates is suggested by the fact that vagally induced ICS contraction is inhibited by naloxone. Thus endogenous opiates in the distal ileum and ICS may be important in the control of intestinal motility and may be part of an endogenous antidiarrheal mechanism.

\section{ACKNOWLEDGMENTS}

The authors would like to thank Ms. Stephanie Medzarentz for her secretarial assistance. Ketocyclazocine was kindly donated by Sterling-Winthrop Research Institute and SKF 10047 by the National Institute on Drug Abuse.

This study was supported in part by research grant R01 AM 19379 from the National Institutes of Health.

\section{REFERENCES}

1. Stewart, J. J., N. W. Weisbrodt, and T. F. Burks. 1978 Central and peripheral actions of morphine on intestinal transit. J. Pharmacol. Exp. Ther. 205: 547-555.

2. Burks, T. F. 1976. Acute effects of morphine on rat intestinal motility. Eur. J. Pharmacol. 40: 279-283.

3. Schulz, R., M. Wuster, and A. Herz. 1979. Centrally and peripherally mediated inhibition of intestinal motility by opioids. Naunyn-Schmiedeberg's Arch. Pharmacol. 308: 255-260.

4. Burks, T. F., and J. P. Long. 1967. Release of intestinal 5-hydroxytryptamine by morphine and related agents. J. Pharmacol. Exp. Ther. 156: 267-276.

5. Northway, M. G., and T. F. Burks. 1979. Indirect intestinal stimulatory effects of heroin: direct action on opiate receptors. Eur. J. Pharmacol. 59: 237-243.

6. Hughes, J., T. W. Smith, H. W. Kosterlitz, L. A. Fothergill, B. A. Morgan, and H. R. Morris. 1975. Identification of two related pentapeptides from the brain with potent opiate agonist activity. Nature (Lond.). 285: 577579.

7. Snyder, S., and R. Simanton. 1977. The opiate receptor and opioid peptides. J. Neurochem. 28: 13-20. 
8. Guillemin, R. 1977. Endorphins, brain peptides that act like opiates. $N$. Engl. J. Med. 296: 226-228.

9. Polak, J. M., S. R. Bloom, S. N. Sullivan, P. Facer, and A. G. E. Pearse. 1977. Enkephalin-like immunoreactivity in the human gastrointestinal tract. Lancet. I: 972-974.

10. Alumets, J., R. Hảkanson, F. Sundler, and K.-J. Chang. 1978. Leu-enkephalin-like material in nerves and enterochromaffin cells in the gut. An immunohistochemical study. Histochemistry. 56: 187-196.

11. Konturek, S. J. 1978. Endogenous opiates and the digestive system. Scand. J. Gastroenterol. 13: 257-261.

12. Lundberg, J. M., T. Hökfelt, J. Kewenter, G. Petterson, H. Ahlman, R. Edin, A. Dahlström, G. Nilsson, L. Terenius, K. Uvnäs-Wallensten, and S. Said. 1979. Substance P-, VIP-, and enkephalin-like immunoreactivity in the human vagus nerve. Gastroenterology. 77: 468-471.

13. Uddman, R., J. Alumets, R. Håkanson, F. Sundler, and B. Walles. 1980. Peptidergic (enkephalin) innervation of the mammalian esophagus. Gastroenterology. 78: 732-737.

14. Lundberg, J. M., T. Hökfelt, A. Änggård, K. UvnäsWallensten, S. Brimijoin, E. Brodin, and J. Fahrenkrug. 1980. Peripheral peptide neurons: distribution, axonal transport, and some aspects on possible function. In Neural Peptides and Neuronal Communication. E. Costa, and M. Trabucchi, editors. Raven Press, New York. 2536.

15. Edin, R., J. Lundberg, L. Terenius, A. Dahlström, T. Hökfelt, J. Kewenter, and H. Ahlman. 1980. Evidence for vagal enkephalinergic neural control of the feline pylorus and stomach. Gastroenterology. 78: 492-497.

16. Ouyang, A., W. J. Snape, Jr., and S. Cohen. 1981. The myoelectrical properties of the ileocecal sphincter of the cat. Am. J. Physiol. 240: 9450-9458.

17. Rubin, M. R., B. A. Cardwell, A. Ouyang, W. J. Snape, Jr., and S. Cohen. 1981. Effect of bethanechol or vagal nerve stimulation on ileocecal sphincter pressure in the cat. Gastroenterology. 80: 974-979.

18. Rubin, M. R., J. Fournet, W. J. Snape, Jr., and S. Cohen. 1980. Adrenergic regulation of ileocecal sphincter function in the cat. Gastroenterology 78: 15-21.

19. Hambrook, J. M., B. A. Morgan, M. J. Rance, and C. F. C. Smith. 1976. Mode of deactivation of the enkephalins by rat and human plasma and rat brain homogenates. Nature (Lond.). 262: 782-783.

20. Meek, J., H.-Y. Yang, and E. Costa. 1977. Enkephalin catabolism in vitro and in vivo. Neuropharmacology 16 15l-154.

21. Chang, K.-J., P. Cuatrecasas, and S. Wilkinson. 1977. The metabolic stability of the enkephalins. Biochem. Biophys. Res. Commun. 74: 1311-1318.

22. Weisbrodt, N. W., and J. Christensen. 1972. Electrical activity of the duodenum during fasting and vomiting. Gastroenterology 63: 1004-1010.

23. Stewart, J. J., N. W. Weisbrodt, and T. F. Burks. 1976. Intestinal reverse peristalsis associated with morphineinduced vomiting. In Opiates and Endogenous Opioid Peptides. H. W. Kosterlitz, editor. Elsevier North-Holland Biomedical Press, Amsterdam. 439-442.

24. Lord, J. A. H., A. A. Waterfield, J. Hughes, and H. W. Kosterlitz. 1977. Endogenous opioid peptides: multiple agonists and receptors. Nature (Lond.). 267: 495-499.

25. Lord, J. A. H., A. A. Waterfield, J. Hughes, and H. W. Kosterlitz. 1976. Multiple opiate receptors. In Opiates and Endogenous Opioid Peptides. H. W. Kosterlitz editor. Elsevier North-Holland Biomedical Press, Amsterdam. 275-280.

26. Smith, A. P., and H. H. Loh. 1980. Heterogeneity of opiate-receptor interaction. Pharmacology. 20: 57-63.

27. Herz, A., R. Schulz, and M. Wüster. 1980. Some aspects of opiate receptors. In Receptors for Neurotransmitters and Peptide Hormones. G. Pepeu, M. J. Kuhar, and S. J. Enna, editors. Raven Press, New York. 329-337.

28. Pruitt, D. B., M. N. Grubb, D. L., Jaquette, and T. F. Burks. 1974. Intestinal effects of 5-hydroxytryptamine and morphine in guinea pigs, dogs, cats, and monkeys. Eur. J. Pharmacol. 26: 298-305.

29. Creese, I., and S. H. Snyder. 1975. Receptor binding and pharmacological activity of opiates in the guinea pig intestine. J. Pharmacol. Exp. Ther. 194: 205-219.

30. Rinaldo, Jr., J. A., E. A. Orinion, R. V. Simpelo, F. E. Check, and W. Beauregard. 1971. Differential response of longitudinal and circular muscles of intact canine colon to morphine and bethanecol Gastroenterology. 60: 438-444.

31. Daniel, E. E., W. H. Sutherland, and A. Bogoch. 1959. Effects of morphine and other drugs on motility of the terminal ileum. Gastroenterology. 36: 510-523.

32. Konturek, S. J., P. Thor, R. Król, A. Dembiński, and A. V. Schally. 1980. Influence of methionine-enkephalin and morphine on myoelectric activity of small bowel. Am. J. Physiol. 238: G384-G389. 